\title{
Sir William Dawson (1820-1899): a very modern paleobotanist
}

\author{
Howard J. Falcon-Lang ${ }^{1}$ And John H. Calder ${ }^{2}$ \\ 1. Department of Earth Sciences, University of Bristol, Bristol BS8 1RJ, U.K. <howard.falcon-lang@bris.ac.uk> \\ 2. Nova Scotia Department of Natural Resources, P.O. Box 698, Halifax, Nova Scotia B3J 2T9 Canada
}

Date received: 9 February 2005 g Date accepted: 27 May 2005

\begin{abstract}
Sir William Dawson was one of Canada's most influential Nineteenth Century geologists. Although a lifelong opponent of the concept of evolution, a stance that resulted in him being sidelined by the scientific community, he made enormous contributions to Pennsylvanian paleobotany, especially at the Joggins fossil cliffs of Nova Scotia. Key to Dawson's success was his recognition of the importance of a field-based research program, in which fossil plants could be observed in their precise geological context over a sustained period of time. Uniquely trained as both geologist and botanist, he was skilled in the microscopic analysis of permineralized plant anatomy, and appreciated the enormous potential of fossil charcoal as an untapped source of systematic information. Arguably his most extraordinary insights came in the field of plant taphonomy, in which studies of modern sedimentary processes and environments were used to interpret the rock record. His analysis of fossil plants in their sedimentary context allowed Pennsylvanian coal swamp communities, dominated by lycopsids and calamiteans, to be distinguished from the coniferopsid forests, which occupied mountainous regions further inland. The lasting significance of Dawson's paleobotanical work is emphasized by many recent papers concerning the Pennsylvanian coal measures of Atlantic Canada, which have either directly built on research topics that Dawson initiated, or have confirmed hypotheses that Dawson framed. Until recent times, the discipline of paleobotany has been dominated by systematic fossil plant description with little or no reference to geological context. By virtue of his distinctively holistic approach, synthesizing all available geological and botanical data, Dawson is marked out from his contemporaries. His methodology does not appear old-fashioned even today, and it is therefore with justification that we describe him as a very modern paleobotanist.
\end{abstract}

\section{RÉSUMÉ}

Sir William Dawson a été l'un des géologues les plus influents du $19^{\mathrm{e}}$ siècle au Canada. Même s'il s'est opposé toute sa vie au concept de l'évolution, une position qui a amené le milieu scientifique à l'ignorer, il a énormément contribué à la paléobotanique pennsylvanienne, spécialement dans les falaises fossilifères de Joggins de la Nouvelle-Écosse. La clé du succès de Dawson réside dans le fait qu'il avait reconnu l'importance d'un programme de recherche sur le terrain prévoyant l'observation des plantes fossiles dans leur milieu géologique particulier pendant une période de temps prolongée. Grâce à sa formation unique de géologue et de botaniste, il possédait la compétence voulue pour réaliser une analyse microscopique de l'anatomie des plantes perminéralisées et il comprenait le potentiel énorme du charbon de bois fossile comme source inexploitée de données systématiques. On pourrait soutenir que ses idées les plus extraordinaires se sont manifestées dans le domaine de la taphonomie végétale, dans lequel des études d'environnements et de processus sédimentaires modernes ont servi à interpréter des antécédents lithologiques. Ses analyses de plantes fossiles dans leur contexte sédimentaire ont permis de distinguer les communautés des marécages houillers pennsylvaniens, dans lesquels prédominent les lycopsides et les calamites, des forêts coniféropsides, qui occupaient les régions montagneuses plus à l'intérieur des terres. De nombreuses communications récentes au sujet des couches houillères pennsylvaniennes des provinces de l'Atlantique, qui s'appuient directement sur des sujets de recherches amorcées par Dawson ou ayant confirmé des hypothèses formulées par Dawson, mettent en reliefl'importance durable des travaux paléobotaniques de Dawson. La discipline de la paléobotanique a jusqu'à tout récemment été dominée par des descriptions systématiques de plantes fossiles évoquant à peine ou n'évoquant pas du tout le contexte géologique. Dawson s'est démarqué de ses contemporains au moyen de son approche nettement holistique en réalisant une synthèse de toutes les données géologiques et botaniques accessibles. Sa méthode de travail ne semble pas rétrograde, même aujourd'hui, et il est par conséquent tout à fait justifié que nous le décrivions en tant que paléobotaniste très moderne.

[Traduit par la redaction] 


\section{INTRODUCTION}

Sir William Dawson (1820-1899) (Fig. 1), long-serving principal of McGill University (1855-1893), was one of Canada's most influential Nineteenth Century geologists (Sheets-Pyenson 1996). He is best remembered as the author of Acadian Geology, a monumental synthesis of Atlantic Canadian geoscience, based largely on his own field observation, and developed through four editions (Dawson 1855a, 1868a, 1878, 1891); it represents over fifty years of painstaking research (Dawson 1901). His life's work covered a bewildering array of topics, and those pertaining to paleobotany spanned the geologic column from the earliest land plants (Dawson 1870) to the Holocene (Dawson 1855c).

Through the course of his later life, and in subsequent historical critiques, Dawson's scientific reputation became tainted (Sheets-Pyenson 1996). This change in fortune principally resulted from his embroilment in several high-profile debates, each of which concluded with Dawson on the losing side. The first concerned the age of the Little River beds of New Brunswick, which Dawson erroneously held to be Devonian (Dawson 1861a), but which were subsequently proven to be Early Pennsylvanian (Stopes 1914). A second controversy erupted around the discovery of putative Precambrian protozoan fossils (Eozoön canadense) in the Canadian Shield, which Dawson claimed to be the earliest evidence for life (Dawson 1864). Many of his contemporaries were highly skeptical of his view that life had originated far deeper in geologic time than previously suggested (a hypothesis that we now know to be cor-

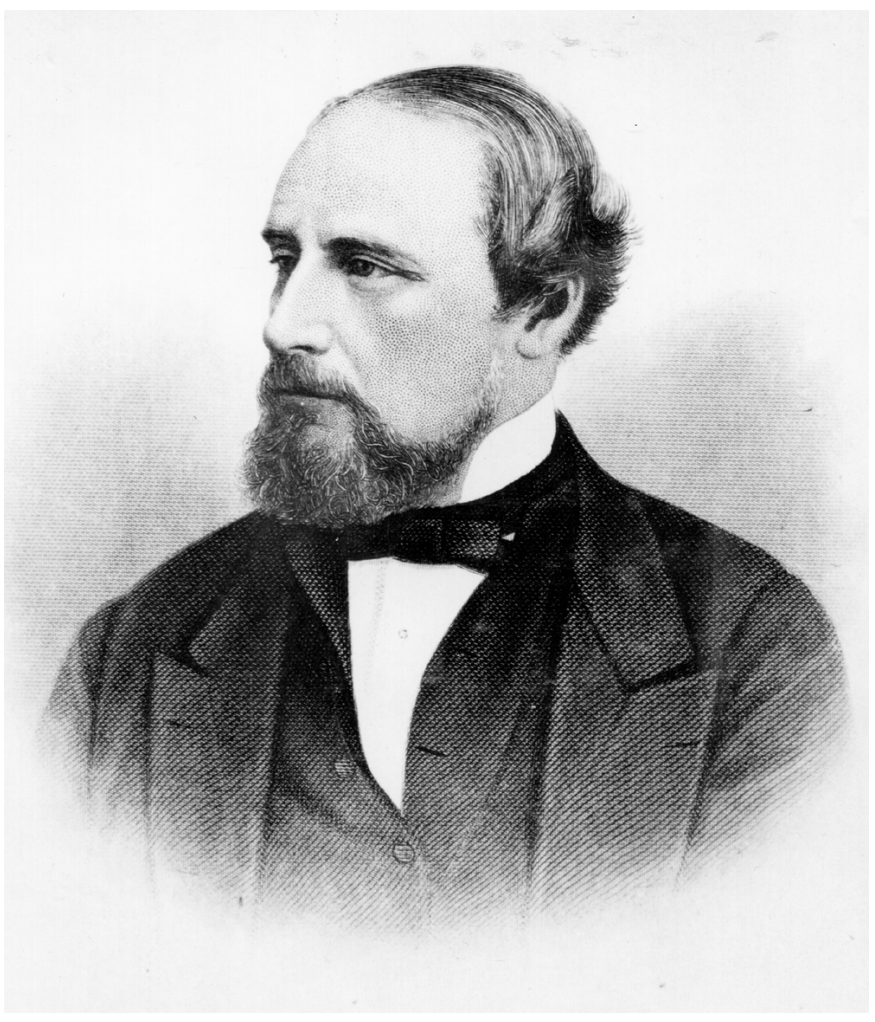

Fig. 1 Portrait of Sir J. William Dawson (1820-1899), about the time he became principal of McGill University in 1855. rect), and, by the end of Dawson's life, Eozoön was interpreted as an abiotic metamorphic phenomenon (Hoffman 2004).

Third and most damagingly of all was Dawson's lifelong rejection of the concept of evolution (Dawson 1875). Dawson adhered to the belief of his mentor Charles Lyell (Thackray 1998) that further discoveries would eventually eradicate the "appearance of progression" in the fossil record (SheetsPyenson 1996). Doubtless, Lyell and Dawson took strength in this conviction from their discovery of the earliest land snails and of the earliest reptiles at Joggins (Lyell and Dawson 1853; Dawson 1860). This strongly held opinion, one consistent with his deep religious convictions, brought Dawson into sharp conflict with leading "evolutionists" of the day. One of these, Darwin's close friend Joseph Hooker, ensured that Dawson's Bakerian Lecture to the Royal Society, a seminal work on Devonian plants, was rejected for publication (Dawson 1870; Sheets-Pyenson 1996). This bitter blow led Dawson to lament that never again would he throw his "pearls before the swine" (Sheets-Pyenson 1991).

Whilst it may be argued that Dawson's critics have generally lacked the subtle understanding necessary to gain a proper scientific and historical context of his ideas, we do not intend to address these controversies here. They have already been amply dealt with in the literature cited above. The sole purpose of this essay is to highlight Dawson's extraordinary contribution to Pennsylvanian coal geology and, in particular, paleobotany. During the early Nineteenth Century, this was a dynamic research field, with new discoveries of fossil forests and related phenomena, reported across Europe and North America each year (e.g., Thomson 1820; Wood 1830; Witham 1831; Hawkshaw 1840; Beckett 1844; Dawes 1844; Brown 1846).

Dawson exerted a massive impact on this developing field and, in the course of our research, we have been struck not only by his careful observational skills and extraordinary productivity, but also by his multidisciplinary approach. As we discuss below, his approach is highly characteristic of contemporary research, and it is therefore with clear justification that we refer to Dawson in the title of this paper as a very modern paleobotanist. Many of his groundbreaking discoveries centred on the famous Joggins fossil cliffs of Nova Scotia, and so it is especially appropriate that our contribution should appear in this issue devoted to Joggins.

\section{FIELD-BASED RESEARCH PROGRAMME}

What was the key characteristic that distinguished Dawson from his fellow paleobotanists? Without doubt it was his recognition of the importance of studying fossil plants in their geological context and, in particular, the development of a sustained field-based research program. In a letter to his friend and mentor, Sir Charles Lyell, dated 13 August 1868, he gave a clear summary of his philosophy, writing that fossil trees were most usefully analyzed "as they stand in the cliffs of Sydney and Joggins" rather than "on the shelves of the British Museum" (Dawson 1868b). This latter comment was probably sparked by 


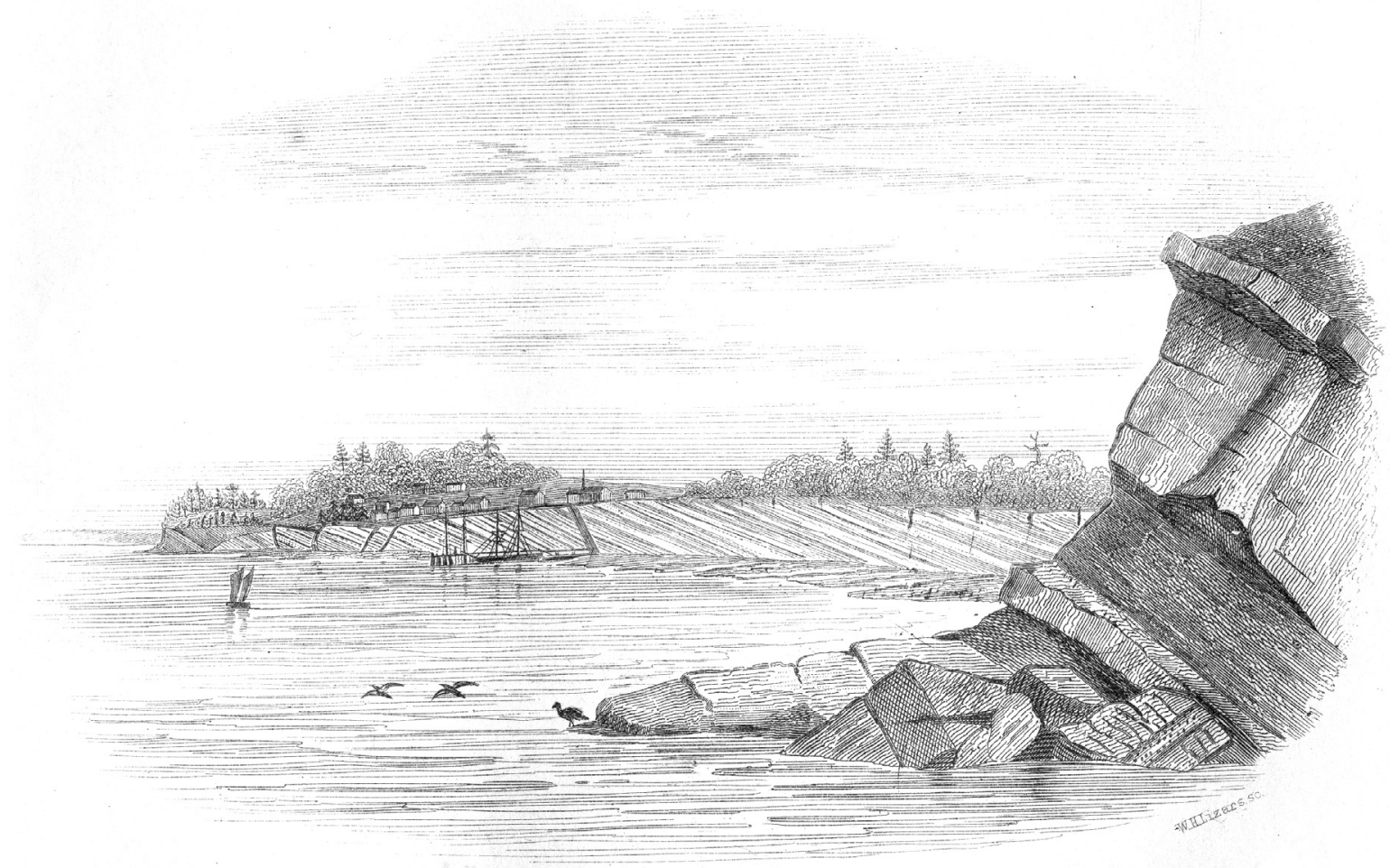

Fig. 2 The "slowly wasting" cliffs of Joggins, where Dawson made some 40 years of sustained geological observation. (Reprinted from Dawson 1868a, p. 179.)

the unsatisfactory practice of so many of his contemporaries, naturalists like Charles Bunbury (1847, 1851), Lyell's brotherin-law, who relied solely on fossil collections made by others for research material.

One event in particular must have reinforced the practical necessity of field-based research in Dawson's mind. Following a productive field season at Joggins (Dawson 1861b), he had some tetrapod material shipped to the leading London anatomist, Richard Owen, carefully boxed, labelled, and ready for systematic description. When Owen's paper on the fossils appeared (Owen 1862), Dawson was horrified to discover that the specimens had somehow become jumbled en route and as a consequence Owen's description was in error in several respects.

Of course, not all of Dawson's colleagues were armchair naturalists. Richard Brown's $(1846,1848,1849)$ work on the fossil forests of Cape Breton, Nova Scotia and Cyrille Grand'Eury's (1877) studies in France stand out as superb examples of fieldbased analyses of coal-measure outcrops. But neither of these geologists matched Dawson's persistence, nor built up such an extraordinary body of careful observation over such an extended period of time. Fieldwork required patience, and Dawson devoted his life to it. Writing of the "slowly wasting" cliffs of Joggins (Fig. 2), he pointed out that "it is only by repeated visits that the geologist can thoroughly appreciate the richness of this remarkable section" (Dawson 1861b, p. 5).

So how did Dawson come to develop this distinctive approach to paleobotany? Growing up amidst exposures of Carboniferous rocks in the seaport of Pictou, Nova Scotia, was a particularly formative experience for the young Dawson, as witnessed by his first discovery of fossil plants as a schoolboy excavating strata behind his school house for use as slate pencils. The influence of his teacher, Thomas McCulloch, at the Pictou Academy and later of Dalhousie University was equally formative (Dawson 1901). Although not directly involved in mining activities, the proximity of Pictou to the Albion Coalfield gave him the opportunity to prospect coal workings and nearby coastal cliffs over many years. It is no surprise then that his earliest scientific papers all dealt with the coal measures geology on his doorstep (Dawson 1845, 1846, 1851, 1855b).

The level of expertise that he developed was soon noticed, and duly impressed two notable gentlemen who came through Pictou in the early 1840s on separate excursions and with whom he would remain lifelong friends: William Logan and Charles Lyell. Dawson correctly advised Logan that the plant fossils he carried with him from the Gaspé were in fact older than the coal measures flora, presaging his Bakerian lecture on Devonian plants to the Royal Society some thirty years later (Dawson 1870). To Lyell he imparted the invaluable advice on the relative age of the redbeds of northern Nova Scotia and Prince Edward Island, which Lyell incorporated in his geological map of eastern North America. Both interactions demonstrated to Dawson the utility of fossil plants, for which he was already developing a passion. 


\section{PERMINERALISED PLANT FOSSILS}

Before addressing the larger question of how Dawson used his geological skills to reconstruct Pennsylvanian forest ecosystems, it is important to first discuss the scope of his fossil plant work. Whereas many paleobotanists were content to study only the commonly preserved compression fossils, Dawson had an additional interest in anatomically preserved plants. Such fossils are formed when plant tissue is mineralized at an early stage, and are comparatively rare in the geological record. Their discovery requires the time-consuming preparation of petrographic thin sections, initially more-or-less on a trial and error basis.

It was during his student years at the University of Edinburgh (1840-1841) that Dawson was first educated in the study of anatomically preserved plants. It was here that he was "introduced to Mr. Sanderson, the lapidary, who sliced fossil wood for Witham" (Dawson 1901, p. 48). Henry Witham was one of the first paleobotanists to investigate the anatomical structure of fossil plants and, during Dawson's student years, Witham's (1831) Observations on Fossil Vegetables was fast becoming a classic. From Sanderson, Dawson "learned something of the art of preparing transparent slices of rocks and fossils for the microscope, which was afterwards of great advantage" (Dawson 1901, p. 48).

On his return to Pictou, Dawson began to patiently apply his new-found skills on local rocks and fossils. In the early 1840 s he discovered that siderite nodules in the Foord seam of the Albion Coalfield contained anatomically preserved plants. With characteristic energy, he set to work "preparing a great number of slices" (Dawson 1846, p. 134), which yielded structurally preserved lycopsid and cordaitalean axes. Although a number of recent papers (Zodrow and Lyons 1992; Zodrow et al. 1996; Lyons et al. 1997) have claimed to have discovered plant-bearing siderite nodules in the Foord seam "for the first time", Dawson was actually aware of them 150 years earlier!

Spurred on by this success, he then began to study the large calcified logs exposed in the cliffs of Pictou Harbour. In one experiment he proved that if the carbonate was totally removed with dilute hydrochloric acid, small fragments of these petrified logs could be burned like modern wood. More significantly, careful thin sectioning showed that these woods possessed an "araucarian structure" identical to the woods of extant Chilean pines (Fig. 3; Dawson 1846). That Dawson, then a young man of only 26 , had such a detailed grasp of wood anatomy indicates the depth and breadth of his early botanical education. As his study (Dawson 1855c) of Holocene stumps on the Bay of Fundy coast shows, he was just as confident analyzing modern wood anatomy as he was with Pennsylvanian fossils. Dawson may have acquired such learning at Edinburgh, where he was influenced by John Hutton Balfour, a botanist with strong interests in fossil plants (Balfour 1872).

In later years, Dawson's skills utilizing anatomically preserved plants were further honed at Joggins. At this famous site, he "sliced specimens from nearly all the ... coaly trees in the section", an extraordinary act of perseverance, especially

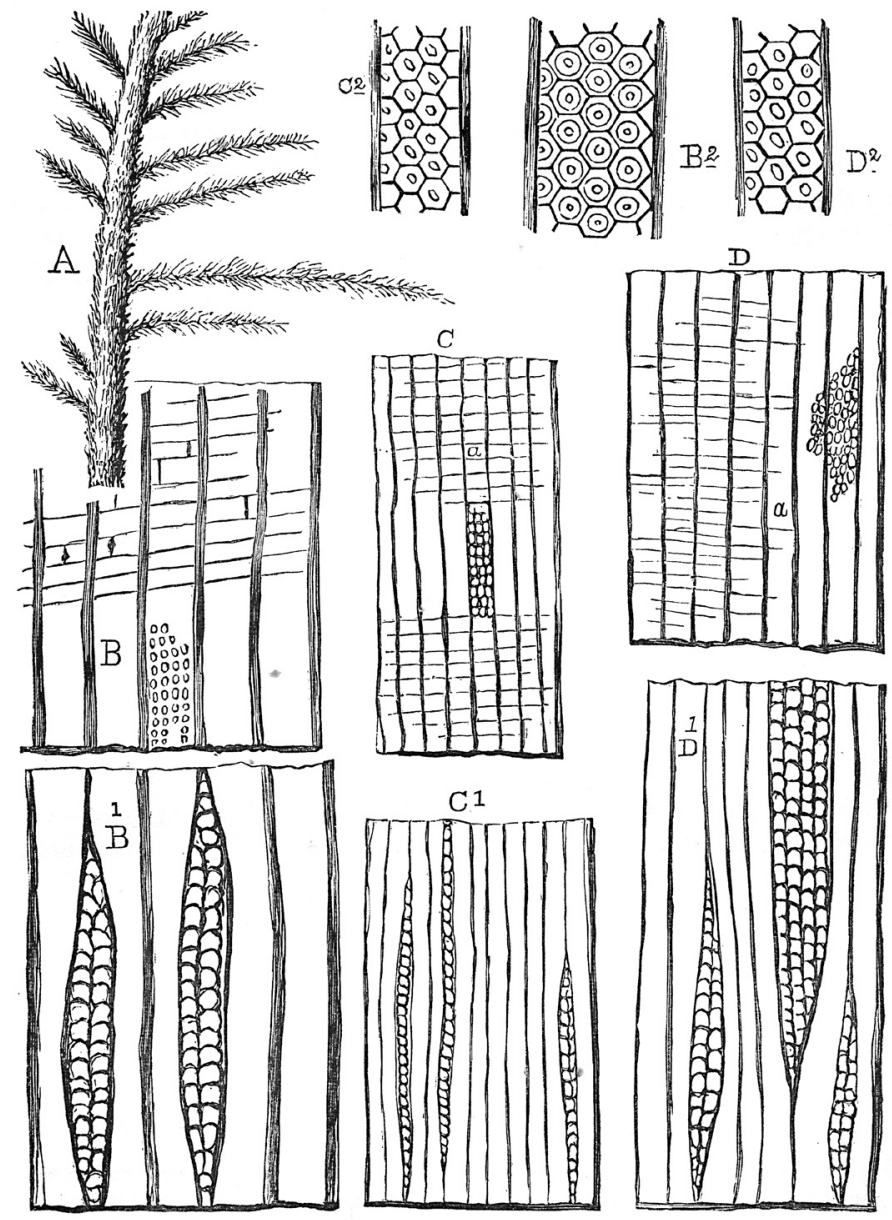

Fig. 3 "Araucarian structure" in cordaitalean "drift trunks" found in channel sandstone bodies at Pictou and Joggins. Dawson incorrectly thought the trunks belonged to walchian conifers. (Reprinted from Dawson 1868a, p. 425.)

given that he only "found structure in two of them" (Dawson 1853, p. 37). Decades later, when an unusually well preserved tree was noted high in the Joggins cliff face, Dawson immediately recognized its importance. He hired a miner to be lowered precariously down the cliff on a ladder (attached by rope to a small tree growing on the cliff-top!), and the fossil was completely recovered (Fig. 4). It proved to be the finest specimen of a lycopsid tree ever extracted from the Joggins section, "having the whole of its woody axis perfectly preserved, in situ, and showing structure" (Dawson 1877, p. 836).

Perhaps one of the rarest, and therefore most significant, discoveries made by Dawson at Joggins was the recognition that, in addition to the common lycopsid trees, a few "conifers" also grew in the coal swamps. Having observed an unusual tree near the level of the "Main Coal", he collected samples to attempt identification (Fig. 5). However "after many trials ... [he] could find only very indistinct traces of cellular tissue" (Dawson 1853, p. 27). Frustrated, yet driven on by curiosity he "had the whole of the tree taken down by a miner", and eventually in "a small portion" he observed diagnostic "hexagonal disks ... of araucarian type" (Dawson 1853, p. 27). This tree was shown 
ultimately to belong to a sister group to the conifers (known as cordaitaleans), and recent research has indicated that it, and other more recently discovered examples, grew in brackish coastal habitats (Falcon-Lang 2005).

\section{CHARCOAL ANALYSIS}

Charcoal was another important source of information used by Dawson to ascertain the anatomy of Pennsylvanian plants. His routine analysis of charcoal ranks as one of his most revolutionary techniques, and perhaps the least well appreciated in the annals of science. Charcoal, the product of wildfire, is extremely abundant in Pennsylvanian rocks and, by virtue of its inert nature, preserves cellular-level plant anatomy in extraordinary detail (Scott 2000). Since the mid-1980s, growing awareness of this latter property, coupled with the development of SEM imaging, has resulted in the widespread use of charcoal as a source of systematic and ecological information (Falcon-Lang 2000). It is therefore all the more amazing that charcoal analysis was a standard part of Dawson's methodological toolbox, some 150 years earlier.

It may well have been Sir Charles Lyell who first pointed out the potential of charcoal to his protégé. With the help ofleading botanist Joseph Hooker, Lyell isolated and figured anatomically preserved plant cells from charcoal in Pennsylvanian coals at Richmond, Virginia, collected during his second trip to North America (Lyell 1847). Growing up in Pictou, Dawson would have been very familiar with fossil charcoal because the Foord coal seam of that region is probably the most charcoal-rich Pennsylvanian coal anywhere in the world.

Interestingly, despite Lyell's confidence that this material “exactly resembles [modern] charcoal” (Lyell 1847, p. 268), and his own descriptive term "mineral charcoal", Dawson appears not to have accepted a fire origin. In an early synthesis on coal formation, Dawson argued that the Foord coal originated under conditions of fluctuating water table, the bituminous coal layers representing "subaqueous putrefaction" of plant material, and intervening charcoal layers, formed by "subaerial decay" (Dawson 1859, p. 627). Dawson shied away from the most obvious interpretation of fossil charcoal because the occurrence of wildfire seemed incompatible with the swamp environment he envisaged for coal formation. He wrote "a substance so intimately intermixed with the ordinary coal cannot be accounted for by the supposition of forest-conflagration" (Dawson 1859, p. 629). This viewpoint remained widely held until the 1970s, and even lingers on today among some coal petrologists (Scott 1989).

As with his studies of permineralized plants, Dawson's charcoal studies were undertaken on a gigantic scale. In his first report, he prepared 200 samples from the Foord coal, using a nitric acid digestion technique, and studied the macerated residue (Dawson 1859). Unfortunately, the light microscopy of Dawson's day required that individual cells be studied in isolation because of the opaque nature of charcoal (Fig. 6). This created enormous problems for Dawson, because individual

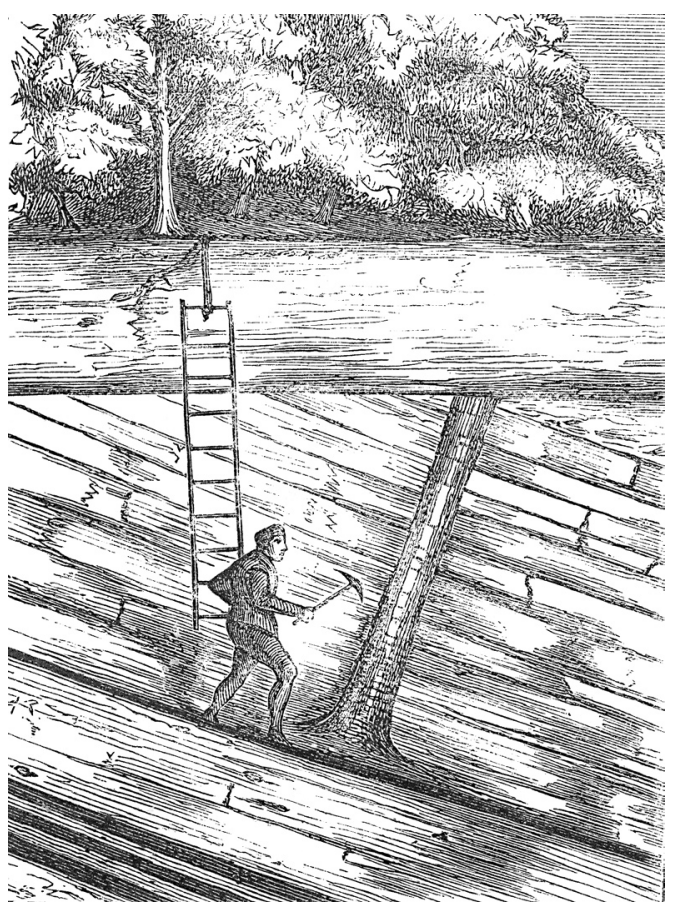

Fig. 4 A miner recovers an anatomically preserved lycopsid tree from the Joggins cliffs, a highly precarious manoeuvre. (Reprinted from Dawson 1877, p. 837.).

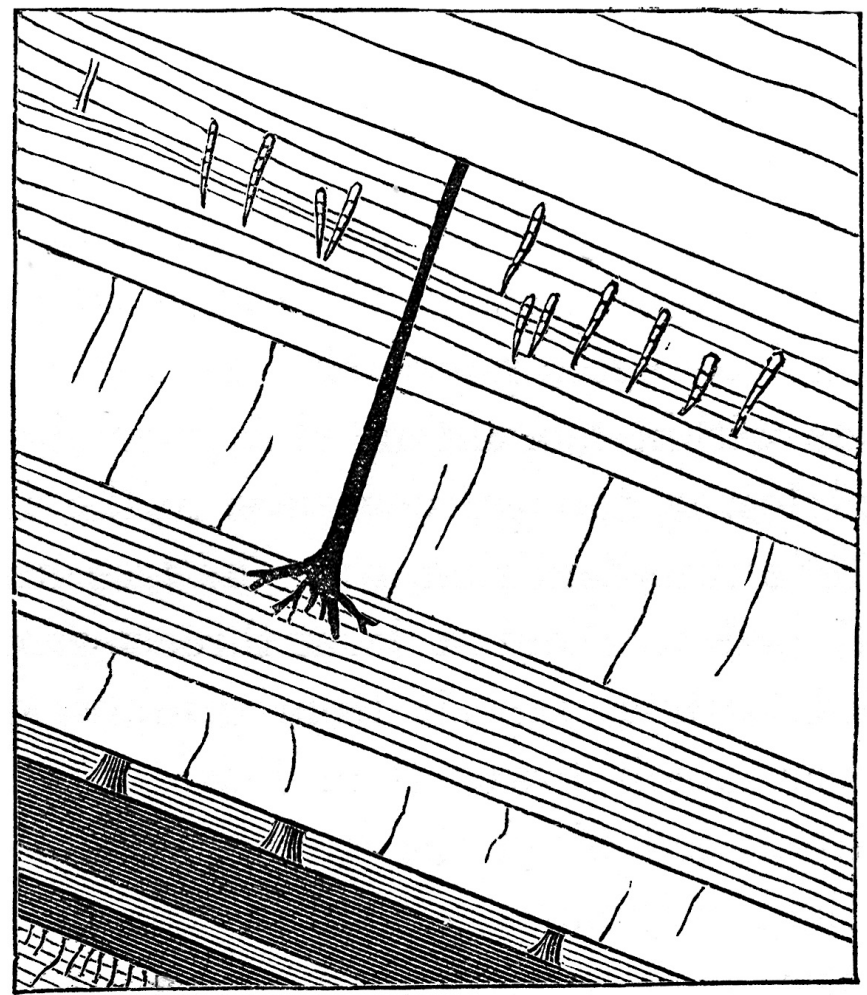

Fig. 5 A "coniferous" (cordaitalean) tree in growth position above the Main Coal at Joggins. Dawson had to repeatedly section this specimen before he was able to identify it. (Reprinted from Dawson 1868a, pp. 198.) 
cells are rarely diagnostic of particular plant groups. Initially, he distinguished "scalariform tissues" interpreted as belonging to lycopsids from "discigenous wood-cells" interpreted as gymnospermous (Dawson 1859, p. 629-630), but later abandoned this overly simplistic system (Dawson 1868a). Today, SEM imaging permits cellular observation in the context of plant tissue, circumventing these problems.

With typical ambition, he then proceeded to macerate charcoal from every coal in the entire Joggins section (Dawson 1865). In an interesting development, he started to collect charred macroscopic plants that exhibited sufficient surface details for traditional identification. From these charred specimens of
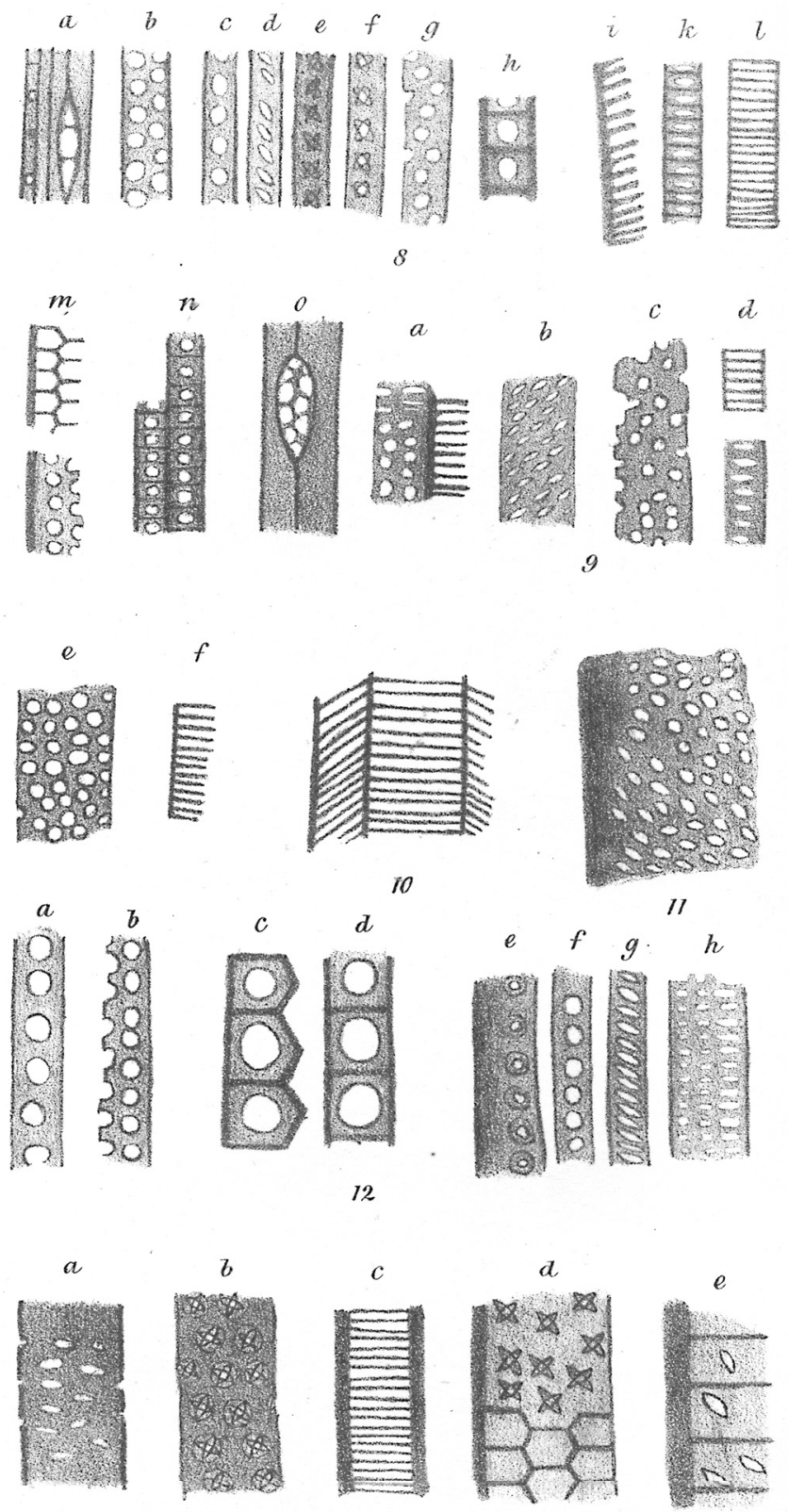

Fig. 6 Cellular anatomy preserved in fossil charcoal from the Foord seam of Pictou. (Reprinted from Dawson 1859, p. 640.)
Calamites, Sigillaria, and others, he then began to catalogue the nature of individual cells, and used these observations to aid identification of dispersed cells, more commonly encountered in the coals (Dawson 1865). Such "phyteral analysis" of coals (Dawson 1859), directly linking microscopic coal constituents with parent plants, remains an under-utilized technique in coal petrography (Calder and Gibling, 1994), and reflects a general lack of paleobotanical knowledge.

\section{WHOLE-PLANT RECONSTRUCTIONS}

Dawson realized that if he was to reconstruct the nature of Pennsylvanian forest communities, a minimum requirement was a rudimentary understanding of the various plants that colonized this environment. The primary difficulty was that the trees were almost never preserved intact, even though specific organs may have been preserved with extraordinary anatomical detail. Whole-plant reconstruction meant that the architecture of Pennsylvanian plants had to be pieced together from isolated organs. This became a key interest for Dawson, attempting "so to restore [fossil plants] that, in imagination, we may see them growing before us, and fancy ourselves walking beneath their shade" (Dawson 1868a, p. 421).

One of the first plants he attempted to reconstruct was the lycopsid Sigillaria. For several years, it had been known that Stigmaria found in the underclay of coals was in fact the rhizophore of Sigillaria (Logan 1841; Brown 1846), and to this evidence Dawson was able to add many other convincing proofs (Fig. 7; Dawson 1846, 1865; Lyell and Dawson 1853). Further reconstruction was facilitated by the discovery of several prone trunks, unbranched and thirty to forty feet in length, in the roof of various Nova Scotian coal seams. These fossils gave an indication of the overall height of the Sigillaria tree (Dawson 1868a).

But beyond this, Dawson's reconstruction of Sigillaria was

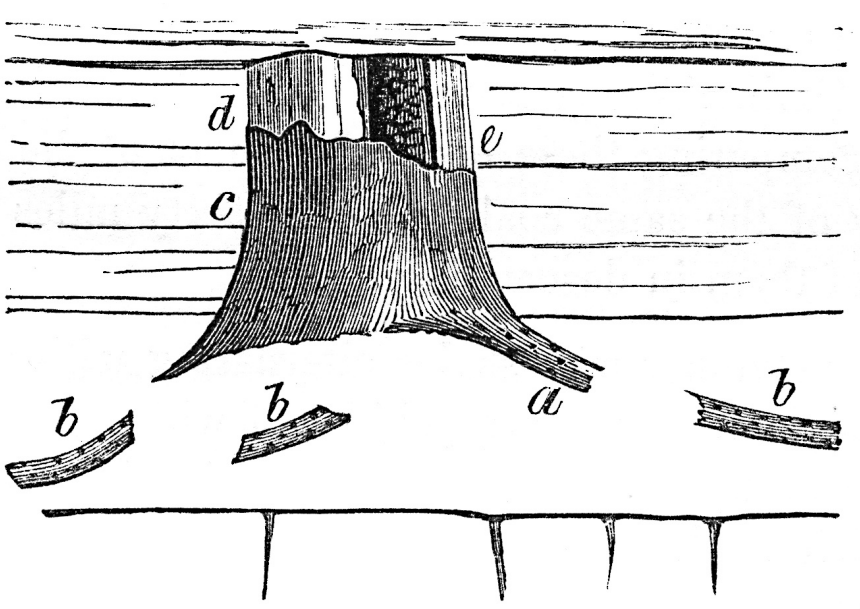

Fig. 7 Sandstone cast Sigillaria tree showing biologically attached Stigmaria rhizophores from Malagash. (Reprinted from Dawson 1868a, p. 216.) 
based on poorly founded supposition, and this must represent the weakest facet of Dawson's otherwise careful and cautious paleobotanical work. For example, he once wrote, "I cannot pretend that I have found the fruit of Sigillaria attached to the parent stem; but I think that a reasonable probability can be established that some at least of the fruits included... Trigonocarpum and Rhabdocarpus" (Dawson 1868a, p. 437). This conclusion was based on the abundance of these seeds in beds rich in Sigillaria, a logical but tenuous connection. Subsequent research has shown that Dawson was quite wrong in this assumption, the fossils being gymnospermous seeds, unrelated to Sigillaria.

Dawson drew another erroneous conclusion from his innovative charcoal work. Finding scalariform tracheids attached to Artisia (his Sternbergia) pith casts, Dawson assumed that at least some of these fossils must have belonged to Sigillaria, based on the common occurrence of scalariform tissue in that plant (Dawson 1859). However, Dawson failed to appreciate that the primary stems of almost all plant groups, not just the lycopsids, contained small amounts of scalariform tissue, and his arguments based on anatomical correspondence were therefore entirely flawed. In subsequent research, the septate piths of Artisia have been shown to be exclusively coniferopsid in affinity.

Tending to base his reconstructions on anatomical similarities, or taphonomic co-occurrence, rather than direct biological connection of adjacent organs, another of Dawson's mistakes was to relate the large permineralized trunks with "araucarian wood" found in Pennsylvanian sandstone bodies to coniferous walchian foliage (Fig. 3; Dawson 1865). In fact, it is now known that most, if not all, permineralized trunks of this age in Nova Scotia belonged to a giant form of cordaitalean, the sister group to the conifers (Falcon-Lang and Scott 2000). Not realizing this relationship, Dawson reconstructed these giant cordaitalean trees as shrubs (Fig. 8).

\section{PLANT TAPHONOMY}

Leaving aside these methodological problems, one of Dawson's greatest contributions to Pennsylvanian paleobotany was his appreciation of plant taphonomy and its significance for reconstructing ecosystems. Although modern facies analysis lay more than a century in the future, Dawson clearly grasped that adjacent sedimentary units in a section represented the ancient deposits of different, but genetically related, environments. Again, in this respect, he may have been strongly influenced by Lyell, who expounded an inductive approach to sedimentology, interpreting small-scale structures in terms of process and environment (Leeder 1998). Dawson realized that by studying fossil plants in the context of sedimentary deposits, major plant communities might be discerned. In the subsequent history of paleobotany, this important approach has been largely overlooked, re-emerging only in the late 1970s (Scott 1978, 1979).

Studying fossil plants in their sedimentary context, Dawson

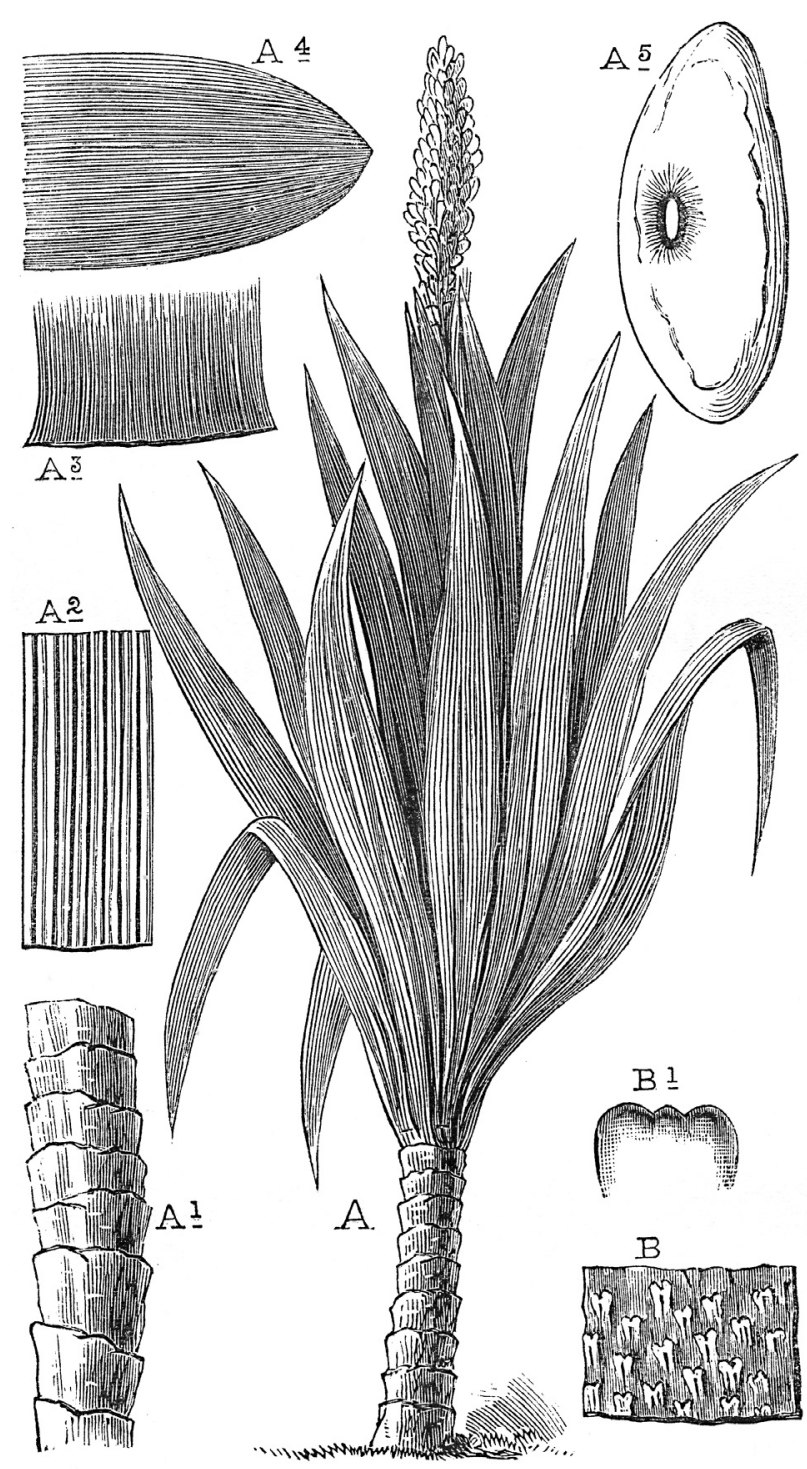

Fig. 8 Dawson erroneously reconstructed the giant cordaitaleans as tiny shrubs. (Reprinted from Dawson 1868a, p. 458.)

was able to distinguish between the vegetation of the wetland coal swamps and that of upland environments further inland. His observation that limestone beds containing a brackish water fauna were interbedded with coal seams at Joggins was formative for his interpretation of the coal swamps. Based on these data, and evidently much influenced by processes in the "modern marshes of the Bay of Fundy" (Dawson 1868a, p. 182), he wrote "I believe that had we visited [Joggins] during the Coal Period, we might, by changing our position a few miles, have passed from a sandy shore to a peaty swamp, or to the margin of an estuary or lagoon" (Dawson 1868a, p. 201).

As fossil trees like calamiteans and the lycopsid Sigillaria were often preserved rooted within coal-bearing deposits, Dawson was in no doubt that these were the main elements of the coal forests, a position borne out by subsequent research (Calder et al. in press). He was particularly interested in the cala- 
mitean trunks, which were rooted in sandy layers, and showed evidence of prolific resprouting following burial (Dawson 1851). These observations clearly proved that calamiteans colonized rapidly aggradational settings (Fig. 9). Furthermore, Dawson understood that such "calamite thickets" could strongly influence patterns of sedimentation. He wrote that having taken root in "soft sludgy material recently deposited or in the process of deposition, [the calamitean thickets] would, by causing water to stagnate, promote the elevation of the surface by new deposits" (Dawson 1868a, p. 195). The influence of plants on presentday patterns of sedimentation has long been understood (e.g. Tansley 1939), but its application to the geological record has been explored only more recently (Underwood and Lambert 1974; Rygel et al. 2004). Although Dawson did not develop his ideas, this observation further emphasizes the innovative nature of his paleobotanical approach and philosophy.

A rather different taphonomic plant assemblage to the calamitean and lycopsid coal forests just described was represented,

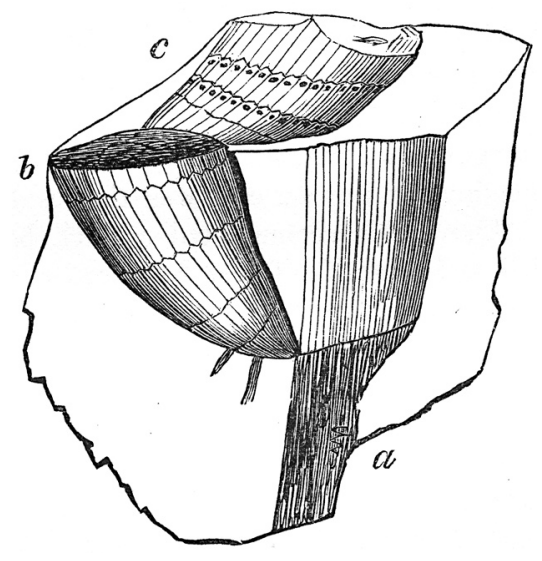

Fig. 9 Calamiteans in growth position at Pictou showing adventitious re-generation (Dawson 1868a, p. 195). at Pictou and Joggins, by the large permineralized trunks found in sandstone bodies. Dawson observed that the sandstone bodies contained channels "cut in clay, and filled with sand and drift trees" (Fig. 10) and he went on to interpret them as the deposits of "tidal and river channels in estuaries ... filled with the debris borne down by an inundation or thrown in by a storm" (Dawson 1853 , p. 13). Some of the trees had evidently been transported a long way for they were "covered with shells of Spirorbis", a fact which "testifies at once to drift and intermission of deposition" (Dawson 1853, p. 12).

As already discussed in the section on permineralized plants, Dawson had identified these "drift trees" as conifer-like plants (cordaitaleans), and it was based on sound taphonomic data that he went on to suggest that they were, in fact, derived from Pennsylvanian mountainous terrains. "It may be inferred that these trees belonged rather to the uplands than to the coalswamps; and the great durability and small specific gravity of coniferous wood would allow it to be drifted, either by rivers or ocean currents, to very great distances" (Dawson 1868a, p. 424). Compared to the coal forests, the "principal habitat [of these giant cordaitalean trees] was farther inland" (Dawson 1853, p. 34). As with much of Dawson's work, recent discoveries in Atlantic Canada have fully confirmed his ground-breaking ideas (Falcon-Lang and Scott 2000; Falcon-Lang and Bashforth 2004).

\section{PALEOBOTANY OF COAL}

Dawson drew on his field-based studies of plant taphonomy and his prowess in microscopy to argue that the origin of coal beds lay not in the aquatic realm, as held for some time by Charles Darwin (1847), but as the accumulation of terrestrial peat. However, Thomas Huxley, ardent defender of Darwin (his nickname was 'Darwin's Bulldog'), continued to argue for

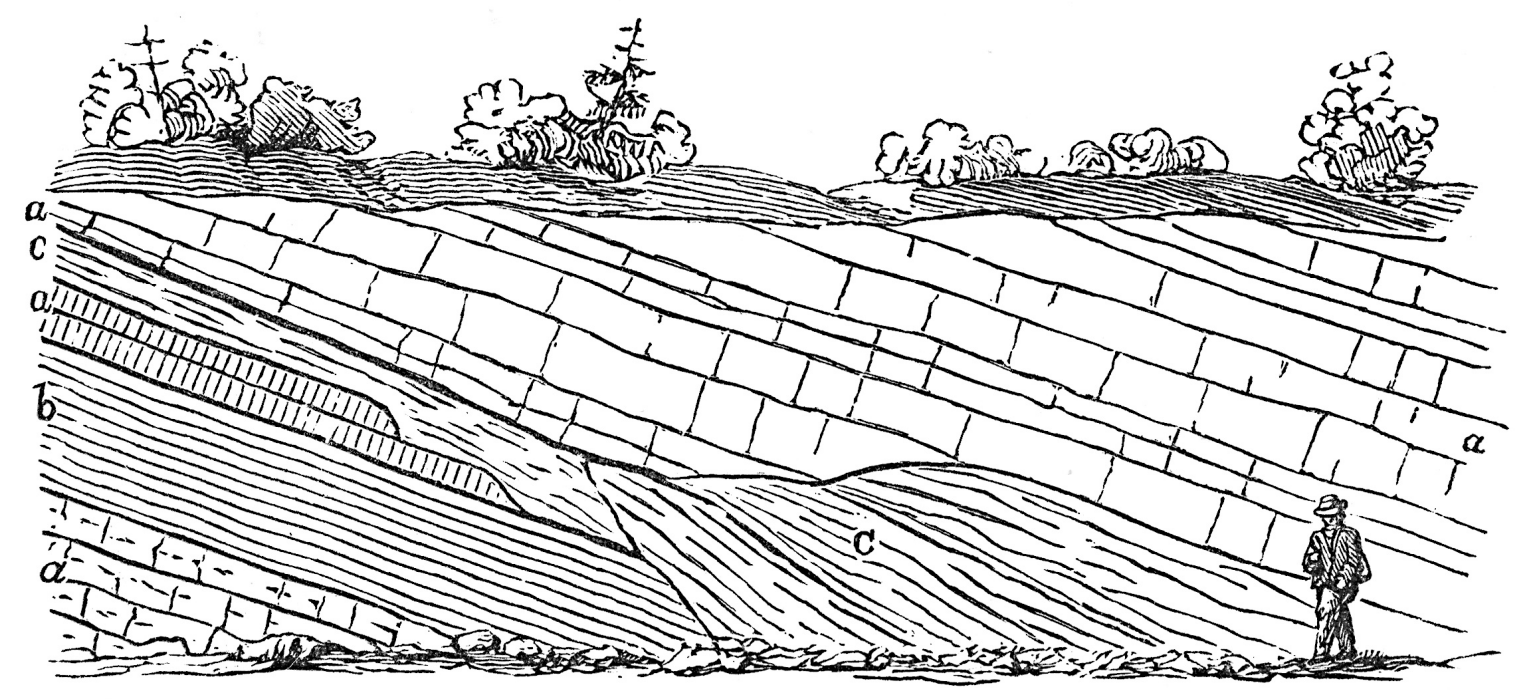

Fig. 10 Channel cuts in Joggins sandstone bodies, interpreted by Dawson as the deposits of an ancient river or tidal channels. (Reprinted from Dawson 1868a, p. 151.) 


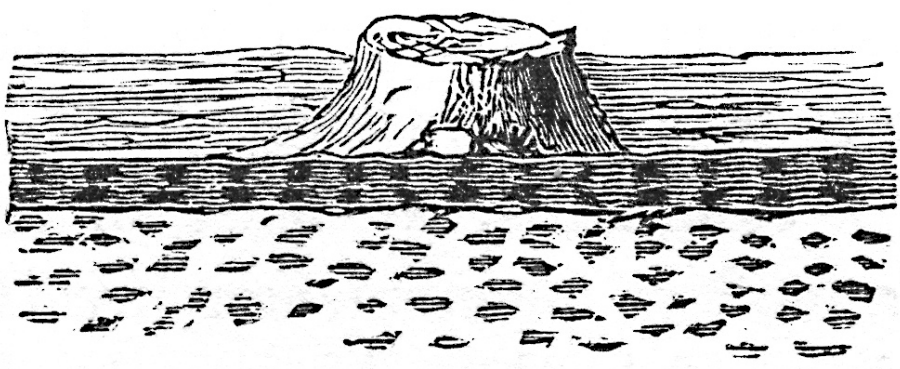

Fig. 11 Submerged Holocene trees preserved on along the Bay of Fundy were pivotal in Dawson's interpretation of flooding surfaces in the Joggins section. (Reprinted from Dawson 1868a, p. 29.)

an aquatic origin for coal, citing as evidence the spores and spore cases in the thin sections of British coal that he examined. Nevertheless, Huxley acknowledged Dawson's command of the field, and allowed, somewhat bemused, that the North America coals examined by Dawson seemed to have had different origins (Huxley 1897). Citing the second edition of Acadian Geology, Huxley wrote, “'The true coal' says Dr. Dawson, 'consists principally of the flattened bark of Sigillarioid and other trees, intermixed with leaves of Ferns and Cordaites, and other herbaceous débris, and with fragments of decayed wood, constituting 'mineral charcoal', all these materials having manifestly alike grown and accumulated where we find them'."

Huxley pressed his case with Dawson, and entreated him to re-examine his coal samples, to which Dawson agreed. His response indicates what we now accept to be the case for the petrographic composition of most Pennsylvanian humic coals (Teichmüller 1982), with the important observation by Dawson that the samples on which Huxley had fixed his gaze were the exception: spore-rich cannel coals. In reply to Huxley on 26 September, 1870, Dawson wrote, "Indications of spore-cases are rare, except in certain coarse shaly coals and portions of coals, and in the roofs of the seams. The most marked case that I have yet met with is the shaly coal [Coal 19 of Joggins] referred to as containing Sporangites in my paper on the conditions of accumulation of coal [Dawson 1865, p. 115, 139 and 165].... The purer coals certainly consist principally of cubical tissues with some true woody matter, and the spore-cases, \&c., are chiefly in the coarse and shaly layers. This is my old doctrine.... Your observations, however, make it probable that the frequent clear spots in the cannels are spore-cases" (Huxley 1897, p. 146). Not only was Dawson correct in his observations of the origin of coal, but he clearly grasped what Huxley had not: that coal beds are not homogenous, and that cannel coals have compositions very different from humic coals derived from peat. He also recognized the importance of palynology in coal analysis (Jansonius and McGregor 1996).

\section{ECOSYSTEMS THROUGH TIME}

One final major insight worth noting was Dawson's appreciation that Pennsylvanian environments and ecosystems changed through time, and the change was cyclical, not random. As already alluded to, Dawson was impressed by the fact that, at Joggins and in the Cape Breton coal measures, coal seams were almost invariably overlain by limestone beds rich in brackish water molluscs like the bivalve Naiadites.

Dawson surmised that "a connexion other than accidental" must have been responsible for these coal-limestone couplets. In hazarding an explanation, he wrote, "probably the peaty areas of coal accumulation were gradually subsiding, and when this process finally caused their submergence, the submerged coalswamp was the most fitting habitat for [the bivalve] Naiadites" (Dawson 1868a, p. 187). In framing this interpretation, he drew on his first hand observation of submerged Holocene forests, scattered along the margin of the Bay of Fundy (Dawson 1868a, p. 32; Fig. 11). He was well aware that significant subsidence could occur in such settings over comparatively short timeintervals. Many Seventeenth Century dykes and adjoining tracts of farmland along the Bay of Fundy had been long since abandoned, and historical records indicated that, each year, tides were rising ever higher (Dawson 1855c).

Whilst Pennsylvanian studies now commonly invoke eustatic sea-level fluctuations linked to glacial-interglacial rhythmicity as the main cause of stratal cyclicity, recent analyses of the Joggins section have emphasized the overriding importance of basinal subsidence in generating flooding surfaces at this site (Davies and Gibling 2003). Whilst glacial eustasy cannot be ruled out, and likely exerted a strong secondary effect, Dawson's interpretation of Joggins cyclicity has proved to be, in part, correct.

\section{CONCLUSIONS}

The figure of Sir William Dawson (1820-1899) still looms large over those of us who study the Pennsylvanian coal measures of Atlantic Canada. Dawson was a multi-faceted giant whose interests and abilities extended well beyond the geological sciences. In this essay we have restricted our focus, and highlighted some of his major contributions to Pennsylvanian paleobotany.

We have shown that, despite his lifelong opposition to the concept of evolution, in regard to his commitment to fieldbased research, plant systematics, taphonomy, and ecosystem reconstruction, Dawson was a very modern paleobotanist, and a scientist well ahead of his time. This is well supported by recent papers on the Joggins fossil cliffs, the subject of this special issue, which have either further developed research areas that Dawson initiated, or confirmed hypotheses that Dawson had framed.

It is still thrilling for us to visit Joggins, the fossil site where 
Dawson made so many of his ground-breaking observation. As he noted, the richness of this amazing section may only be appreciated through study over a long period of time. More than 150 years after Dawson first walked these cliffs with Sir Charles Lyell, perhaps what we have learnt most of all is just how much more remains to be discovered, not only in the emerging cliffs, but in the work of those who preceded us. Most notable among these was Sir William Dawson.

\section{ACKNOWLEDGEMENTS}

HFL acknowledges receipt of a NERC Post-doctoral Fellowship (NER/I/2001/00738) held at the University of Bristol and John Calder acknowledges a Paleontology Research Grant (1999) from the Museum of Nova Scotia. We thanks the editors of this issue for affording us the pleasure of many happy hours reading Dawson's work. We thank Bill Chaloner and Andrew MacRae for their helpful reviews.

\section{REFERENCES}

BALFOUR, J.H. 1872. Introduction to the study of palaeontological botany. Adam and Charles Black, Edinburgh, 118 p.

Beckett, H. 1844. On a fossil forest in the Parkfield Colliery near Wolverhampton. Quarterly Journal of the Geological Society of London, 1, pp. 41-43.

BROwn, R. 1846. On a group of erect fossil trees in the Sydney Coalfield of Cape Breton. Quarterly Journal of the Geological Society of London, 2, pp. 393-396.

BRown, R. 1848. Description of an upright Lepidodendron with Stigmaria roots in the roof of the Sydney Main Coal in the island of Cape Breton. Quarterly Journal of the Geological Society of London, 4, pp. 46-50.

BRown, R. 1849. Description of erect Sigillariae with conical taproots found in the roof of the Sydney Main Coal in the island of Cape Breton. Quarterly Journal of the Geological Society of London, 5, pp. 354-360.

Bunbury, C.J.F. 1847. On the fossil plants from the coal formation of Cape Breton. Quarterly Journal of the Geological Society of London, 3, pp. 423-438.

Bunbury, C.J.F. 1851. Description of a peculiar fossil fern from the Sydney Coalfield, Cape Breton. Quarterly Journal of the Geological Society of London, 8, pp. 31-35.

Calder, J.H., \& Gibling, M.R. 1994. The Euramerican Coal Province: controls on Late Paleozoic peat accumulation. Palaeogeography, Palaeoclimatology, Paleoecology, 106, pp. 1-21.

Calder, J.H., Gibling, M.R., Scott, A.C., \& Hebert, B.L. in press. A fossil lycopsid forest succession in the classic Joggins section of Nova Scotia: paleoecology of a disturbance-prone Pennsylvanian wetland. In Wetlands through time. Edited by S. Greb and W.A. DiMichele. Geological Society of America Special Paper.
DARwin, C. 1847. Letter to J.D. Hooker (undated). In The life and letters of Charles Darwin. Edited by F. Darwin. D. Appleton \& Co., New York, 1905, vol. 1, pp. 324

Davies, S.J., \& Gibling, M.R. 2003. Architecture of coastal and alluvial deposits in an extensional basin: the Carboniferous Joggins Formation of eastern Canada. Sedimentology, 50, pp. 415-439.

DAWES, J.S. 1844. Some account of a fossil tree in the Coal Grit near Darlaston, south Staffordshire. Quarterly Journal of the Geological Society of London, 1, pp. 46-47.

DAwson, J.W. 1845. On the new coal formation of the eastern part of Nova Scotia. Quarterly Journal of the Geological Society of London, 1, pp. 322-330.

Dawson, J.W. 1846. Notices of some fossils found in the coal formation of Nova Scotia. Quarterly Journal of the Geological Society of London, 2, pp. 132-136.

Dawson, J.W. 1851. Notice on the occurrence of upright Calamites near Pictou, Nova Scotia. Quarterly Journal of the Geological Society of London, 7, pp. 194-196.

Dawson, J.W. 1853. On the coal measures of the South Joggins, Nova Scotia. Quarterly Journal of the Geological Society of London, 10, pp. 1-42.

DAwson, J.W. 1855a. Acadian Geology: An account of the geological structure and mineral resources of Nova Scotia, and portions of the neighbouring provinces of British America. $1^{\text {st }}$ Edition. Oliver and Boyd, Edinburgh \& Montreal, 388 p.

DAwson, J.W. 1855b. Notice of a discovery of a reptilian skull in the coal of Pictou. Quarterly Journal of the Geological Society of London, 11, p. 8.

Dawson, J.W. 1855c. On a modern submerged forest at Fort Lawrence, Nova Scotia. Quarterly Journal of the Geological Society of London, 11, pp. 119-122.

Dawson, J.W. 1859. On the vegetable structures in coal. Quarterly Journal of the Geological Society of London, 15, pp. 626-641.

DAWson, J.W. 1860. On a terrestrial mollusk, a millepede, and new reptiles, from the coal formation of Nova Scotia. Quarterly Journal of the Geological Society of London, 16, pp. 268-277.

DAwson, J.W. 1861a. On the pre-Carboniferous flora of New Brunswick, Maine and eastern Canada. Canadian Naturalist, 6, pp. 161-180.

Dawson, J.W. 1861b. Notice of the discovery of additional remains of land animals in the coal-measures of the South Joggins, Nova Scotia. Quarterly Journal of the Geological Society of London, 18, pp. 5-8.

DAwson,J.W.1864. On the structure of certain organic remains in the Laurentian limestones of Canada. Quarterly Journal of the Geological Society of London, 21, pp. 51-59.

Dawson, J.W. 1865. On the conditions of the deposition of coal, more especially as illustrated by the coal-formation of Nova Scotia and New Brunswick. Quarterly Journal of the Geological Society of London, 22, pp. 95-169.

DAwson,J.W.1868a. Acadian geology: the geological structure, 
organic remains, and mineral resources of Nova Scotia, New Brunswick, and Prince Edward Island. $2^{\text {nd }}$ Edition. Oliver and Boyd, Edinburgh \& Montreal, $694 \mathrm{p}$.

Dawson, J.W. 1868b. Letter to Charles Lyell, 13 August 1868. John William Dawson Papers, McGill Archives.

Dawson, J.W. 1870. On the pre-Carboniferous floras of northeastern America with especial reference to that of the Erian (Devonian) period. Proceedings of the Royal Society, 199, p. 2.

Dawson, J.W. 1875. The dawn of life; being the history of the oldest known fossil remains, and their relations to geological time and the development of the animal kingdom. Dawson Brothers, Montreal. 239 p.

Dawson, J.W. 1877. Note on a specimen of Diploxylon from the coal formation of Nova Scotia. Quarterly Journal of the Geological Society of London, 33, pp. 836-842.

DAwson,J.W. 1878. The geological structure, organic remains, and mineral resources of Nova Scotia, New Brunswick and Prince Edward Island or Acadian Geology, $3^{\text {rd }}$ Edition. Macmillan and Co., London, 694 pp, with a supplement, pp. 1-102.

DAwson, J.W. 1891. The geology of Nova Scotia, New Brunswick and Prince Edward Island. or Acadian Geology, $4^{\text {th }}$ Edition, Macmillan \& Co., London, 694 pp, with 2 supplements, pp. 1-102, and pp. 1-37.

Dawson, J.W. 1901. Fifty years of work in Canada, scientific and educational. Ballantyne, Hanson \& Co., Montreal, $308 \mathrm{p}$.

Falcon-Lang, H.J. 2000. Fire ecology of the Carboniferous tropical zone. Palaeogeography, Palaeoclimatology, Palaeoecology, 164, pp. 339-355.

FALCon-LANG, H.J. 2005. Small cordaitalean trees in a marine-influenced coastal habitat in the Pennsylvanian Joggins Formation, Nova Scotia, Canada. Journal of the Geological Society of London, 162, pp. 485-500.

FAlCon-LANG, H.J., \& BASHForth, A.R. 2004. Pennsylvanian uplands were forested by giant cordaitalean trees. Geology, 32 , pp. 417-420.

Falcon-Lang, H.J., \& ScotT, A.C. 2000. Upland ecology of some Late Carboniferous cordaitalean trees from Nova Scotia and England. Palaeogeography, Palaeoclimatology, Palaeoecology 156, pp. 225-242.

Grand'Eury, F.C. 1877. Mémoire sur la flore carbonifère du département de la Loire et du centre de la France, étudiée aux trois points de vue botanique, stratigraphique et géognostique. Mémoires de l'Académie des Sciences de l'Institut de France, 24, pp. 1-624.

Hawкshaw, J. 1840. Further observations on the fossil trees found on the Manchester and Bolton railway. Proceedings of the Geological Society of London, 1, pp. 269-270.

Hoffman, H.J. 2004. Precambrian fossils in Quebec. In Actes du premier colloque du patrimoine géologique du Québec. Edited by G. Pichonnet and M.A. Bouchard. Géologie Québec, MB 2004-05, pp. 109-113 (published as a CD)
Huxley, T.H. 1897. Discourses: biological and geological essays. D. Appleton and Company, New York, 388 p.

Jansonius, J., \& McGregor, D.C. 1996. Introduction. In Palynology: principles and applications. Volume 1. Edited by J. Jansonius, \& D.C. McGregor. American Association of Stratigraphic Palynologists Foundation, Dallas, pp. 1-10.

LEEDER, M.R. 1998. Lyell's principles of geology: foundations of sedimentology. In Lyell: the past is the key to the present. Edited by D.J. Blundell, \& A.C. Scott. Geological Society Special Publication, 143, pp. 97-110.

LoGAN, W.E. 1841. On the character of the beds of clay lying immediately below the coal seams of South Wales. Proceedings of the Geological Society of London, 3, pp. 487-492.

Lyell, C.J. 1847. On the structure and probable age of the coalfield of the James River near Richmond, Virginia. Quarterly Journal of the Geological Society of London, 3, pp. 261-280.

LyELL, C.J., \& DAwson, J.W. 1853. On the remains of a reptile (Dendrerpeton acadianum, Wynam \& Owen) and of a land snail discovered in the interior of an erect fossil tree in the coal measures of Nova Scotia. Quarterly Journal of the Geological Society of London, 9, pp. 59-63.

Lyons, P.C., Zodrow, E.L., Millay, M.A., Dolby, G., GilLIS, K.S., \& Cross, A.T. 1997. Coal-ball floras of Maritime Canada and palynology of the Foord seam: geologic, palaeobotanical and palaeoecological implications. Review of Palaeobotany and Palynology, 95, pp. 31-50.

Owen, R. 1862. Description of specimens of fossil reptilia discovered in the coal measures of the South Joggins. Quarterly Journal of the Geological Society, London, 18, pp. 238-245.

Rygel, M.C., Gibling, M.R., \& Calder, J.H. 2004. Vegetation-induced sedimentary structures from fossil forests in the Pennsylvanian Joggins Formation, Nova Scotia. Sedimentology, 51, pp. 531-552.

ScoTT, A.C. 1978. Sedimentological and ecological control of Westphalian B plant assemblages from West Yorkshire. Proceedings of the Yorkshire Geological Society, 41, pp. 461-508.

ScotT, A.C. 1979. The ecology of Coal Measure floras from northern Britain. Proceeding of the Geologists' Association, 90, pp. 97-116.

Sсотт, A.C. 1989. Observations on the nature and origin of fusain. International Journal of Coal Geology, 12, pp. 443-475.

Sсотт, A.C. 2000. The pre-Quaternary history of fire. Palaeogeography, Palaeoclimatology, Palaeoecology, 164, pp. 281-329.

Sheets-Pyenson, S. 1991. "Pearls before swine": Sir William Dawson's Bakerian lecture of 1870. Notes and Records of the Royal Society of London, 45, pp. 177-191.

Sheets-Pyenson, S. 1996. John William Dawson: hope, faith and science, McGill-Queen's University Press, Montreal, $274 \mathrm{p}$. 
Stopes, M.C. 1914. The "Fern Ledges" Carboniferous flora of St. John, New Brunswick. Geological Survey of Canada, Memoir, 41, $142 \mathrm{p}$.

Tansley, A.G. 1939. The British Islands and their vegetation. Cambridge University Press, 2 volumes, 484 p.

TeIChmüller, M. 1982. Origin of the petrographic constituents of coal. In Stach's textbook of coal petrology. $3^{\text {rd }}$ Edition. Edited by E. Stach, Gebrüder Borntraeger, Berlin, 535 p.

ThackRAY, J.C. 1998. Charles Lyell and the Geological Society. In Lyell: the past is the key to the present. Edited by D.J. Blundell and A.C. Scott. Geological Society of London, Special Publication, 143, pp. 17-20.

Thomson, T. 1820. Article XII: scientific intelligence, and notices of subjects connected with science. Annals of Philosophy, 16, pp. 388-390.

Underwood, J.R., \& LAMBERT, W. 1974. Centroclinal cross strata, a distinctive sedimentary structure. Journal of Sedimentary Research, 44, pp. 1111-1113.

Wiтнам, H. 1831. Observations on fossil vegetables accompa- nied by representations of their internal structure, as seen through the microscope. William Blackwood, Edinburgh and T. Cadell, London, $48 \mathrm{p}$.

Wood, N. 1830. Account of some fossil stems of trees, found penetrating through the strata above the High Main Coal, at Killingworth Colliery, at a depth of 48 fathoms. Transactions of the Natural History Society of Northumberland, 1 , pp. 205-215.

Zodrow, E.L., \& Lyons, P.C. 1992. The first discovery of in situ coal balls in Nova Scotia. Nova Scotia Department of Natural Resources, $11^{\text {th }}$ Open House and Review of Activities, Program, pp. 4-5.

Zodrow, E.L., Lyons, P.C., \& Millay, M.A. 1996. Geochemistry of autochthonous and hypautochthonous coal balls (Foord seam, Bolsovian, Upper Carboniferous), Nova Scotia, Canada. International Journal of Coal Geology, 29, pp. 199-216.

Editorial responsibility: Robert A. Fensome 